\title{
Artikkeli
}

\section{Livetviittaaminen jalkapallon} MM-kisojen mediaspektaakkelissa - Sosiaalisen television faniutuva yleisö

Tässä artikkelissa tarkastellaan suomalaisen Twitter-yleisön faniutumista jalkapallon MM-kisojen mediaspektaakkelissa.' Tutkimusaineisto koostuu Ylen kisastudiolähetyksistä ja yleisön lähettämistä \#ylemmfutis-tviiteistä vuoden 2014 jalkapallon MM-kisojen aikana. Fanius nähdään tutkimuksessa sosiaalisena konstruktiona, jota lähestytään diskursiivisen position käsitteen kautta. Televisiolähetystä ja yleisön livetviittaamista tarkastellaan kolmesta sosiaalisen television näkökulmasta (virtuaalinen olohuone, performatiivinen näyttämö, pseudoyhteisö), joissa faniuden keskeiset näkökulmat (affektiivisuus, aktiivisuus, sosiaalisuus) yhdistetään digitalisoitumisen myötä syntyneisiin uusiin viestinnän mahdollisuuksiin (reaaliaikaisuus, julkisuus, interaktiivisuus). Tutkimuksen perusteella mediaspektaakkeliin liittyvä fanius voidaan käsittää tietynlaisena trendifaniutena, jota leimaa faniuden hetkellisyys sekä yleisön ja fanin rajan hämärtyminen.

AVAINSANAT: Sosiaalinen televisio, livetviittaaminen, Twitter, fanius, diskursiivinen positio, mediaspektaakkeli

K erran neljässä vuodessa pelattava jalkapallon MM-lopputurnaus on yksi maailman katsotuimmista mediaspektaakkeleista, joka kerää yleisökseen paitsi intohimoisia jalkapallokannattajia myös poikkeuksellisesta mediajuhlasta ja -rituaalista nauttivia satunnaiskatsojia (Kolamo \& Vuolteenaho 2014, 68). Uuden median aikakaudella katsojan ei tarvitse enää tyytyä sivustaseuraajan rooliin, vaan spektaakkeliin on mahdollista ottaa osaa erilaisten sosiaalisen median kanavien välityksellä. Tällaista televisio-ohjelmaan osallistumista kutsutaan sosiaaliseksi televisioksi (Mukherjee \& Jansen 2014). Uudenlainen osallistuva katsojuus muokkaa perinteisiä aktiivisen ja passiivisen yleisön roolikäsityksiä ja liudentaa siten fanin ja mediakuluttajan rajaa. (Rowe \& Hutchins 2014, 9). 
Tässä artikkelissa tarkastellaan suomalaisen Twitter-yleisön faniutumista jalkapallon MM-kisojen mediaspektaakkelissa. Sosiaalisen television näkökulmasta tämä tarkoittaa huomion kiinnittämistä sekä yleisön lähettämiin tviitteihin että televisiolähetykseen, jotka yhdessä konstruoivat faniuden merkityksiä. Lähtökohtanani on siten yhtäältä ajatus katsojista oman diskursiivisien fanipositionsa tuottajina (Heinonen 2005, 82), ja toisaalta näkemys Ylen televisiolähetyksestä yleisön faniuttajana (Nikunen 2005). Erityisen kiinnostavaa tutkimukseni kannalta on se, ettei suomalaisille televisionkatsojille ole tarjolla "luonnollista" kannatuskohdetta (Heinonen $2005,19)$, koska Suomi ei ole mukana lopputurnauksessa. Näin ollen yleisölle ei ole tarjolla valmiita fanipositioita, vaan katsojat joutuvat tuottamaan positionsa lähtökohtaisesti itse. Tutkimuskysymykseni rakentuvat siten seuraavasti:

1) Miten ja millaisiin fanipositioihin yleisö asettaa itsensä? 2) Miten Ylen kisastudio osallistuu yleisön konstruoimiseen?

\section{Fanit yleisöinä, yleisöt faneina - jalkapallokatsojuus sosiaalisessa televisiossa}

Tässä osiossa tarkastelen faniuden ja yleisöyden muotoja uuden median aikakaudella ja esitän, miten sosiaalista televisiota hyödynnetään oman mielekkään katsomiskokemuksen rakentamiseen. Lähestyn faniutta erilaisissa fanimääritelmissä toistuvien elementtien kautta, joista nostan keskiöön affektiivisuuden, aktiivisuuden ja sosiaalisuuden näkökulmat. Faniutta leimaa vahva affektiivinen side yleisön ja tekstin välillä, ja siihen liitetään erilaiset fanitoiminnat, joiden kautta fanius tehdään näkyväksi. Myös faniyhteisöön kuuluminen katsotaan usein fanin pakolliseksi ominaisuudeksi. (Nikunen 2005, 47, 50-52.) Tarkastelen elementtejä kietoutuneina sosiaalisen television reaaliaikaisuuden, julkisuuden ja interaktiivisuuden käytäntöihin siten, että niiden risteyksessä syntyy kolmenlaisia sosiaalisen television ulottuvuuksia, joita tässä nimitän virtuaaliseksi olohuoneeksi (Harringtonin ym. 2012), performatiiviseksi näyttämöksi (Papacharissin 2012) ja pseudoyhteisöksi (Wohn \& Na 2011).

Faniuden karkailevaa käsitettä on pyritty kesyttämään järjestämällä sitä erilaisin luokituksin, joista yksi tunnetuimmista lienee Abercrombien ja Longhurstin (1998) jako kuluttajiin, faneihin, kultisteihin, entusiasteihin ja pientuottajiin. Luokituksessa fanius järjestyy jatkumolle fanin sitoutumisen asteen, fanimateriaalin tuotannon määrän ja fanien välisen vuorovaikutuksen perusteella. Samansuuntaiseen luokitteluun on päätynyt Richard Giulianotti (2002), joka omassa tutkimuksessaan on jakanut jalkapallokatsojat kannattajiin, seuraajiin, faneihin ja flanööreihin joukkueeseen panostamisen, siihen sitoutumisen ja identifioitumisen perusteella. Siinä missä kannattajat ja seuraajat muodostavat perinteisen, paikallisuuteen perustuvan katsojuuden, näyttäytyvät fanit ja flanöörit pikemminkin kuluttajina. Kannattajan pitkäaikainen emotionaalinen suhde joukkueeseensa on luokittelussa vastakohtana flanöörin sensaatiohakuiselle elämysten etsimiselle, jossa joukkueeseen sitoutuminen 
on pinnallista. (Emt., 33, 39.) Giulianottin $(2002,39)$ mukaan televisio ja internet räätälöivät jalkapalloa yhä enemmän juuri flanööreille sopiviksi kokemuspaketeiksi esittäessään ottelun spektaakkelimaisina toimintakohtauksina.

Faniuden kohteen medianäkyvyydestä riippuvaiset flänöörit ja fanit ovat nähdäkseni lähellä Kaarina Nikusen (2005) trendifanin ja Harri Heinosen $(2005,249)$ postfanin käsitteitä, joissa korostuu median luoma ajankohtaisuus ja faniuden hetkellisyys. Mikko Hautakangas $(2008,170)$ puhuukin trendifaniudesta tietynlaisena määräaikaisena prosessina, josta on helppo irrottautua. Jalkapalloyleisöjä tutkinut Heinonen (2005, 249-250) korostaa postfanin kohdalla lisäksi kannattamisen leikinomaisuutta ja lempijoukkueen tietoista valitsemista. Arthur Raneyn (2006, 341) mukaan katsomiskokemuksen mielekkyys onkin riippuvainen katsojan ja joukkueiden välisistä affektiivisista kytköksistä. Globaalit urheiluspektaakkelit toimivat varsin hedelmällisenä alustana trendifaniudelle, sillä ne koetaan Sami Kolamon ja Jani Vuolteenahon (2014, 67-68) mukaan usein jo lähtökohtaisesti ainutkertaisina tapahtumina ja poikkeustiloina, joihin urheilua yleensä seuraamattomatkin haluavat osallistua. Nick Couldry $(2005,60)$ pitääkin suuria mediatapahtumia jaettuina rituaaleina, joiden kautta katsoja linkittää itsensä sosiaaliseen maailmaan. Oleellista katsojalle on tällöin kuvitelma yhteisestä katsomisesta ja tässä ja nyt -kokemuksesta.

Näen Riikka Turtiaisen $(2008,56)$ tapaan erilaisten fanikategorioiden tarjoavan kattavan kokonaiskuvan mediakuluttamisen moninaisuudesta, vaikkei kategorioita itsessään voikaan pitää likimainkaan selvärajaisina. Affektiivisuuden, aktiivisuuden ja sosiaalisuuden mittareilla jäsentyneet fanikategoriat ovat perustuneet vastakkainasettelulle kuluttajan ja tuottajan välillä, mutta digitalisoitumisen myötä tuo raja on hämärtynyt (Booth 2010, 22). Henry Jenkins (2006a, 3) puhui jo kymmenen vuotta sitten mediakonvergenssista, jolla hän korosti yleisökäytäntöjen muutosta tuottamisen ja kuluttamisen tavoissa. Oleellista on, että yleisöä ei nähdä pelkästään passiivisena mediatekstin kuluttajana vaan myös sen aktiivisena tuottajana.

Mediakonvergenssin käsitteeseen sisältyy lisäksi ajatus mediateknologioiden välisestä yhteistyöstä, millä viitataan etenkin vanhan ja uuden median väliseen vuorovaikutukseen (Jenkins 2006a, 2). Internetin ja sen alustojen hyödyntämisen on pelätty uuden median alkuajoista lähtien johtavan television kuolemaan (Jenkins 2006a, 5), mutta viimeaikaisten tutkimusten (Highfield ym. 2013, 318) valossa uudet digitaalisen median verkostot ennemminkin täydentävät televisionkatsomiskokemusta kuin uhkaavat sen olemassaoloa. Tabletin, älypuhelimen tai muun oheisnäytön kautta tapahtuvaa televisiokatsojien välistä vuorovaikutusta on kutsuttu viimeaikaisissa tutkimuksissa yhtäällä sosiaaliseksi televisioksi (Wohn \& Na 2011; Giglietto \& Selva 2014; Qihao \& Raney 2015) ja toisaalla livetviittaamiseksi (Highfield ym. 2013; Schirra ym. 2014; Qihao \& Raney 2015). Näen sosiaalisen television käsitteenä kuvaavan televisiolähetyksen ja Twitterin luomaa digitaalista tilaa kokonaisuutena, livetviittaamisella viittaan yleisön toimintaan tuossa jaetussa tilassa.

Vaikka yleisön aktiivinen rooli mediatekstin osallistujana ja tulkitsijana on mediaja yleisöntutkimuksessa pitkään tunnustettu, ovat erilaiset sosiaalisen median alus- 
tat mahdollistaneet näkyvämmän yhteisöllisen ja osallistuvan televisionkatselun. Esimerkiksi Matikainen ja Villi $(2015,149)$ huomauttavat, ettei yleisöistä välttämättä ole tullut aiempaa aktiivisempia, mutta niiden toiminnasta on tullut verkon mahdollistamana näkyvämpää. Erilaisten fanikäytäntöjen omaksuminen "tavallisen" yleisön keskuudessa on saanut tutkijat puhumaan yleisöjen faniutumisesta (Jenkins 2006b, 142). Verkon tarjoamat mahdollisuudet osallistua ja tuoda ilmi omaa suhdettaan mediatekstiin tekevät ennen vain pienen faniyhteisön piiriin kuuluneista käytännöistä valtavirtaa ja hämärtävät entisestään yleisön, mediakuluttajan ja fanin määritelmiä (Turtiainen 2008: 54).

Toisaalta aktiivistunut yleisö on herättänyt myös mediatuotannon osallistamaan ja faniuttamaan yleisöjään entistä intensiivisemmin. Vaikka ohjelmaan sitouttaminen ei olekaan uusi ilmiö, on se saanut uudenlaisia muotoja etenkin sosiaalisen television aikakaudella. Mediayhtiöt hyödyntävät digitaalisia välineitä tarjoamalla ohjelmilleen virallisia hashtagejä, joiden kautta katsojia kannustetaan osallistumaan dialogiin televisio-ohjelman ja muiden katsojien kanssa. (Harrington 2013, 241-242.) Hautakangas $(2008,166)$ käyttää käsitettä aktivoitu yleisö korostamaan yleisön ja median molemminpuolista panostusta yleisösuhteeseen: yleisö on aktiivinen tulkitessaan tekstiä, mediateksti on aktiivinen kutsuessaan yleisöä panostamaan omaan yleisöyteensä.

Erityisen suosittua tviittaamiseen kannustaminen on erilaisten livelähetysten aikana. Jenkinsin (2006b, 141) mukaan mediafanien faniuden käytännöt ovatkin kietoutuneet tv-ohjelmien rytmiin, mikä tarkoittaa sitä, että fanit pyrkivät keskustelemaan ohjelmasta mahdollisimman reaaliaikaisesti. Lisäämällä tarjotun hashtagin tviittinsä katsoja liittyy osaksi hetkellisen hashtag-yhteisön jaettua katsojuutta, jossa katsoja voi ilmaista suhdettaan mediatekstiin. Kutsun tätä sosiaalisen television ulottuvuutta Harringtonin ym. (2012) termein virtuaaliseksi olohuoneeksi, jonka näen eritoten välittömän reagoinnin mahdollistavana tilana. Tulkitsen tämän ulottuvuuden liittyvän faniuden elementeistä erityisesti affektiivisuuteen, sillä se korostaa katsojan (emotionaalista) suhdetta tulkitsemaansa mediatekstiin. Tällaisia tviittaajan välittömiä reaktioita mediatekstiin on sosiaalisen television kontekstissa tutkittu aiemmin lähinnä teemoittelemalla tviittejä niiden tyylien ja sisältöjen perusteella (Wohn \& Na 2011;Tuomi 2013; Giglietto \& Selva 2014), mutta myös selvittämällä tviittipiikkejä eli sitä, missä kohtaa ohjelmaa on lähetetty eniten tviittejä (Anstead \& O'Loughlin 2011; Alonso \& Shiells 2013 ; Highfield ym. 2013; Yu \& Wang 2015).

Faniutta on määritelty paitsi affektiivisuuden myös aktiivisuuden kriteerein. Nikusen $(2005,50)$ mukaan fanitoiminta on faniuden näkyvää pintaa, ja sen kautta on usein erotettu fanit muusta yleisöstä. Näkyvyyteen liittyy erityisesti ajatus performanssista, joka on olennainen osa kaikkea faniutta ja siihen liittyvää kokemusta (Bennett \& Booth 2015). David Rowen ja Stephanie Bakerin $(2012,307)$ mukaan mediajulkisuus kannustaa yleisöä performoimaan omaa innostustaan ja saa aikaan liioiteltuja faniuden ilmauksia. Turtiainen $(2008,62)$ esittääkin julkisuuden itsessään tuottavan fanimaisia käytäntöjä. Borenin ja Hickmanin (2013) mukaan Twitter hou- 
kuttelee fanitoimintaan myös niitä, jotka eivät tavallisesti ole aktiivisia fanisivuston käyttäjiä. Julkisuuden ulottuvuus erottaakin sosiaalisen television muista (fanien) verkkokeskusteluista.

Livetviittaaminen näyttäytyy siten faniuden ja itsen esittämisen mahdollistavana kanavana. Kutsun tätä sosiaalisen television ulottuvuutta performatiiviseksi näyttämöksi. Käsitteellä korostan Zizi Papacharissin (2012) tavoin Goffmanin dramaturgiseen vuorovaikutusteoriaan viitaten tviittaajien suorittavan identiteettiään erilaisilla "näyttämöillä". Tviittaaja esittää faniuttaan esimerkiksi fanitavaroiden, fanikäytäntöjen tai tietynlaisen kielellisen ilmaisun kautta. Sosiaalisen television kontekstissa jo pelkästään ohjelman virallisen hashtagin käyttö tviitissä on eräänlainen performanssi: faniuden esittämistä hashtagin luomalle kuvitteelliselle yleisölle (Wilson 2011, 451). Glee-fanien toimintaa Twitterissä tutkineet Wood ja Baughman (2012, 329) näkevät sosiaalisen median käytön osana televisionkatsomisprosessia tarjoavan aktiiviselle yleisölle uudenlaisia mahdollisuuksia toteuttaa omia luovia fanikäytäntöjään. Myös esimerkiksi Highfield ym. (2013) sekä D’Heer ja Verdegem (2015) korostavat sosiaalisen television performatiivista ulottuvuutta tulkitessaan yleisöjen tviittauskäytäntöjä julkisiksi performansseiksi kuulumisesta tietyn mediaspektaakkelin yleisöön.

Faniuden sosiaalinen elementti rakentuu kuvitellun yhteisön (Anderson 1983/2006) käsitteen ympärille. Fanius rakentuu yhteisöistä, joiden kautta voidaan tehdä eronteko meidän ja muiden välille. Yhteisöt eivät useinkaan ole tiiviitä ja selvärajaisia, eivätkä niiden jäsenet välttämättä koskaan tapaa toisiaan kasvotusten (Anderson 2006,6 ). Kuvitellun yhteisön käsite sopii hyvin jaetun mediarituaalin katsojien välisen yhteisen katsomiskokemuksen hahmottamiseen, sillä livelähetyksen katsominen luo tunteen kuulumisesta tiettyyn tulkintayhteisöön (Deller 2011, 224). Nikunen $(2005,329)$ puhuu kuvitelluista yleisöistä, joilla hän viittaa mediajulkisuuden luomiin ideaaliyleisöihin, joihin katsojat suhteuttavat itseään ja toisiaan. Televisiolähetys luo tietynlaisia faniasemia, joihin tarjotaan paikoin varsin konkreettisiakin faniuden toimintamalleja (Nikunen 2005, 90). Käsitettä voidaan lähestyä myös faniuden esittämisen näkökulmasta, jolloin merkittäväksi muodostuu se, kenelle faniutta esitetään.

Sosiaalisessa televisiossa kuviteltu yhteisö ja yleisö kietoutuvat toisiinsa: tviittaaja on samaan aikaan sekä osa yleisöä että itse esiintyjä. Kutsun tätä sosiaalisen television ulottuvuutta Wohnin ja Nan (2011) tavoin pseudoyhteisöksi. Heidän mukaansa Twitterin kautta käyttäjät luovat yhteisöllisyyttä, vaikka eivät olisikaan suoraan dialogissa toistensa kanssa. Liittämällä tietyn hashtagin tviittiinsä katsoja liittää samalla itsensä osaksi laajaa hashtag-yhteisöä sen sijaan, että osoittaisi tviitin pelkästään seuraajilleen. Hashtagin ympärille syntynyt hetkellinen yhteisö koostuu pääosin samoista kuvitellun yhteisön jäsenistä, jotka televisiokatsoja on voinut kuvitella yhteisen katsomiskokemuksen ääreen jo ennen internetiä. Nyt yhteinen kokemus on kuitenkin mahdollista kielellistää ja ilmentää interaktiivisesti. Sosiaalisen television kontekstissa tviittaaja on lisäksi kuvitellulle yleisölle esiintyjä. Jokainen performanssi on siten merkityksellinen vasta saadessaan kuvitellun yleisön, jota varten performanssi toteutetaan (Papacharissi 2012, 1989). 
Suuri osa sosiaalisen television tutkimuksesta onkin keskittynyt tähän ilmiön sosiaaliseen ja interaktiiviseen ulottuvuuteen, joskin varsin erilaisista lähtökohdista kuin tässä tutkimuksessa. Hajautunutta yleisöä on jäsennetty ja yleisön jäsenten välistä vuorovaikutusta on kartoitettu etenkin verkostoanalyysin avulla (Highfield ym. 2013, Highfield 2013, Larsson 2013). Sen ansiosta on voitu tutkia tviittaajien suhteita ja linkittymistä toisiinsa.

Tässä tutkimuksessa tarkastelen uuden median faniutta tietynlaisena hetkellisenä sosiaalisena konstruktiona. Oleellista ei ole nimetä tai luokitella jalkapallokatsojia ulkopuolelta, vaan tarkastella katsojia oman merkityksellisen katsomiskokemuksensa tuottajana. Näin ollen tarkoituksenani ei ole etsiä "aitoja" faneja, koska näen faniuden, katsojuuden ja kuluttajuuden käsitteiden leikkaavan toisiaan. Lähtökohtanani on ajatus tviittaamiskäytäntöjen hyödyntämisestä faniuden rakennusaineena. Livetviittaamisen kautta katsojat tuottavat fanipositioitaan eri tavoin erilaisista faniuden ulottuvuuksista. Affektiivinen, aktiivinen ja sosiaalinen fani rakentuu siten tilanteisesti televisiolähetyksen ja Twitterin risteyksessä.

\section{Diskursiivinen positiointi teoreettisena viitekehyksenä}

Tutkimukseni lähtökohdat ovat sosiaalisessa konstruktivismissa, jossa todellisuus nähdään kielellisessä vuorovaikutuksessa rakentuneena. Tarkemmin sanoen tutkimukseni teoreettista taustaa voisi kuvata diskursiiviseksi merkitysten tutkimukseksi, jossa korostan kieltä funktionaalisina ja asioita aikaansaavina tekoina.

Keskeisessä osassa on monikerroksinen konteksti, jota mallinnan tutkimuksessani etenkin systeemis-funktionaalisen kieliteorian näkökulmasta. Teoria korostaa kontekstin kerroksellisuutta sekä käsitystä kielen ja kontekstin välisestä dialogisuudesta. Yhtäältä kieli luo kontekstia ja toisaalta konteksti vaikuttaa kielen käyttöön (Heikkinen ym. 2000, 119, 197.) Egginsin ja Martinin $(1997,243)$ genre- ja rekisteriteoriassa konteksti kuvataan kahdella tasolla: välittömänä tilannekontekstina ja laajempana kulttuurikontekstina. Näen Heikkisen ym. $(2000,66)$ tavoin ideologian luovan näiden kontekstien ympärille vielä yhden, yleisemmän tason kontekstin.

Tutkimukseni kannalta oleellista ovat näiden kontekstien väliset suhteet. Kulttuurikonteksti toimii tilannekontekstin kontekstina vaikuttaen siihen, mitä ylipäätään kussakin tilanteessa on mahdollista tehdä, mitä tilanteessa on lupa odottaa ja kuinka siinä tulee toimia. Toisaalta jokainen yksittäinen tilanne uusintaa tai muokkaa olemassa olevia käsityksiä normeista ja konventioista. Ideologia toimii kaiken ympärillä uskomus-, arvo- ja moraalijärjestelmänä. Sen olemassaolo on usein implisiittistä ja luonnollistunutta. (Heikkinen 1999, 85, 90.) Koska tässä artikkelissa kiinnostukseni kohteena ovat mediaspektaakkeliin osallistujat ja heidän tuottamansa paikat mediatekstissä, esittelen alla olevassa kuviossa oman näkemykseni osallistujien erilaisista toimijaulottuvuuksista kullakin kontekstitasolla. 
Kuvio 1. Toimijaulottuvuudet eri kontekstitasoilla

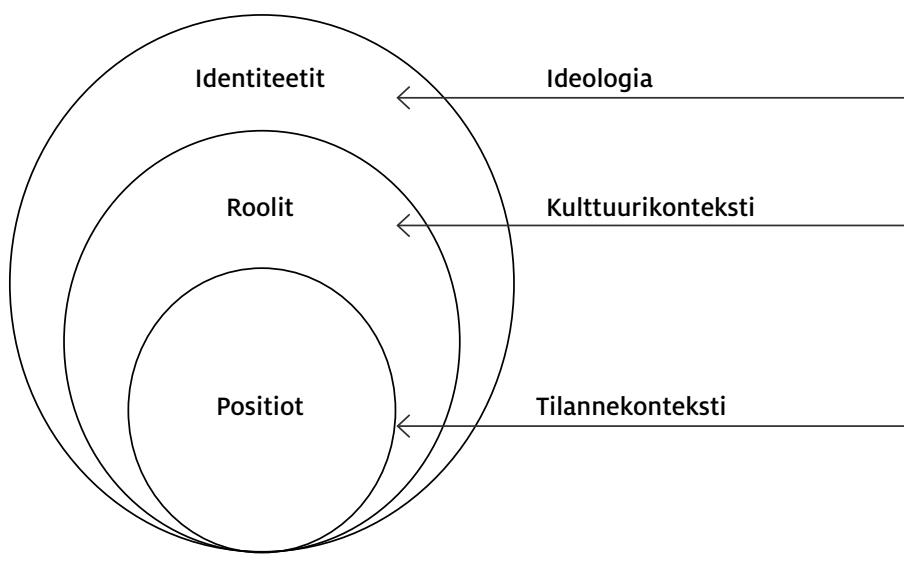

Kuviosta on havaittavissa jako kolmeen kontekstin tasoon, joilla muodostuu eritasoisia toimija-asetelmia. Tässä artikkelissa huomioni kiinnittyy ensi sijassa tilannekontekstin tasoon, jossa osallistujat tuottavat itselleen, tai heille tuotetaan, tilannekohtaisia rooleja tai identiteettejä, joita tässä nimitän positioiksi (esim. Jokinen ym. 1993, 39, Davies \& Harré 1990). Wood ja Kroger (2000, 100-101) määrittelevät positiot tilanteisiksi puhuja-asemiksi, joiden kautta vuorovaikutuksen osapuolista tulee keskustelun osapuolia. Rooleilla viittaan positioita vakaampiin toimintatyyppeihin, jotka usein määrittävät valmiiksi tietynlaisia oletettuja positioita (Zimmerman 1998, 90²), joista osallistuja voi kuitenkin kieltäytyä. Osallistujien roolikonventiot puolestaan määräytyvät laajempien yhteiskunnallisten ja sosiaalisten kulttuuriarvojen perusteella. Näen siten roolien ja positioiden takana abstraktin sosiaalisen identiteetin, johon itseä ja muita suhteutetaan. Näin identiteetin, roolin ja position käsitteet kietoutuvat yhteen, ja ne onkin usein niputettu varsin väljästi identiteetin käsitteen alle. Esimerkiksi Norman Fairclough $(1997,167)$ käyttää identiteetin käsitettä kuvaamaan laajasti kaikkien kontekstitasojen toimijaulottuvuuksia, vaikka myöntääkin, että yhden osallistujan identiteetti voi olla monisyinen ja hoitaa samanaikaisesti useita tehtäviä. Davies ja Harré (1990) korostavat positiointia nimenomaan diskursiivisten käytäntöjen kautta tapahtuvina prosesseina. Elda Weizmanin $(2008,14)$ mukaan positiointia leimaa interaktiivisuus ja refleksiivisyys: positioimalla itsensä puhuja asemoi samalla myös interaktiivisesti muut osapuolet, positioimalla muut hän asemoi refleksiivisesti myös itsensä.

Näen kulttuurikontekstin konventionaaliset ja sosiaaliset roolit kontekstina tilanteisesti rakentuville positioille. Tietyn genren suhteellisen vakaat roolit toimivat siten eräänlaisina ennakko-oletuksina positioille. Esimerkiksi televisiokeskustelussa toimittajalta odotetaan tietynlaisia positioita, joihin asettuessaan hän uusintaa olemassa olevia rooleja. Toisaalta toimittaja voi haastaa ja kyseenalaistaa oman roolinsa asettumalla institutionaaliselle roolilleen epäkonventionaaliseen positioon. Positio-käsitteen käyttökelpoisuus omassa tutkimuksessani piileekin nimenomaan sen dynaami- 
sessa ulottuvuudessa, joka suhteellisen stabiilista rooli-käsitteestä puuttuu (Weizman 2008, 16). Määrittelemällä positiot tilannekontekstin, roolit kulttuurikontekstin ja identiteetit ideologian osallistujiksi, haluan korostaa, ettei tutkimuksessani mielekästä ole selvittää "aitoja" fani-identiteettejä, vaan kiinnostuksen kohteeksi nousee se, miten fanius tuotetaan tilanteisina positioina (Jokinen ym. 1993, 37).

\section{Jalkapallon MM-kisat Ylellä ja Twitterissä}

Tutkimukseni kohdistuu Brasiliassa pelatun jalkapallon MM-kisojen lopputurnauksen televisiolähetyksiin Ylen kanavilla 12.6.-13.7.2014. Kisojen aikana pelattiin yhteensä 64 ottelua, jotka kaikki televisioitiin suorana Yleisradion kanavilla. Yle tarjosi katsojilleen erilaisia mahdollisuuksia osallistua lähetykseen, joista tutkimukseni kannalta keskeisin osallistamiskeino oli lähetykselle omistettu virallinen hashtag \#ylemmfutis. Sisällyttämällä hashtagin tviittiinsä, katsojan oli mahdollista paitsi keskustella reaaliaikaisesti muiden ohjelman katsojien kanssa myös saada tviittinsä hetkeksi televisioruudulle.

Tarkastelen aineistoa monipuolisesti sosiaalisen television näkökulmista kiinnittäen huomiota sekä Ylen kisastudiolähetyksiin että ohjelman virallisen hashtagin ympärillä käytyyn keskusteluun Twitterissä. Havaintojeni perusteella jalkapallon MM-kisoihin liittyvä trendifanius liittyy monipuolisesti mediaspektaakkelin eri tasoille. Samanlaisia havaintoja on tehnyt Tim Highfield (2013), jonka tutkimuksen mukaan Tour de Francen aikana itse kilpailu on vain yksi osa Twitterissä käytyä keskustelua. Lähetysspesifi hashtag tarjoaakin yleisölle mahdollisuuden kommentoida spektaakkelia viihdepakettina, johon liittyvät myös esimerkiksi studiovieraat ja itse spektaakkeli (Emt., 255-256). Keskityn tässä artikkelissa kuitenkin ainoastaan joukkueisiin kohdistuvaan faniuden muotoon.

Tutkimusaineistoni koostuu viidestä MM-ottelulähetyksestä, niiden kisastudioosuuksista ja otteluiden aikana lähetetyistä \#ylemmfutis-tviiteistä. Otteluista kolme (Meksiko-Kamerun, Kolumbia-Norsunluurannikko ja Algeria-Venäjä) on alkusarjan pelejä, yksi (Kolumbia-Uruguay) neljännesvälierä ja yksi (Brasilia-Saksa) välierä. Ottelut on valittu turnauksen eri vaiheista mahdollisimman monipuolisen aineiston takaamiseksi. Ne ovat erityyppisiä paitsi painoarvoltaan, myös pelaavien joukkueiden tai niiden tähtipelaajien nauttiman (media)suosion osalta. \#ylemmfutis-tviitit olen kerännyt Twitter search -työkalun avulla. Anstead ja O'Loughlin $(2011,7)$ huomauttavat, ettei tällä työkalulla kerätty aineisto koskaan sisällä kaikkia haetun hashtagin tviittejä. Tämä ei kuitenkaan ole ongelma tutkimuksessani, jossa viiden ottelun tviiteistä olen saanut koottua kattavan ja riittävän saturoituneen aineiston. 
Taulukko 1. Tviittien kokonaismäärät ja fanipositiotviittien määrä aineistossa.

\begin{tabular}{|l|c|c|}
\hline Ottelu & Tviitit/ottelu & Fanipositiotviitit \\
\hline Meksiko-Kamerun & 693 & 46 \\
\hline Kolumbia-Norsunluurannikko & 722 & 87 \\
\hline Algeria-Venäjä & 443 & 32 \\
\hline Kolumbia-Uruguay & 627 & 79 \\
\hline Brasilia-Saksa & $\mathbf{4 7 0 0}$ & 560 \\
\hline Yhteensä & $\mathbf{7 2 0 0}$ & $\mathbf{8 0 4}$ \\
\hline
\end{tabular}

Taulukossa 1 on nähtävissä tarkastelemani viiden ottelun tviittien kokonaismäärät. Huomattava määrä koko aineistoni tviiteistä sijoittuu Brasilian ja Saksan väliseen välieräotteluun, mitä selittää ensinnäkin kahden suuren jalkapallomaan kohtaaminen turnauksen loppumetreillä, ja toiseksi ottelun yllätyksellinen luonne (Saksa voitti 7-1). Taulukossa on nähtävissä myös viiden ottelun tviiteistä manuaalisesti sisällönanalyysin keinoin seulotut fanipositiotviitit, joilla tarkoitan sellaisia tviittejä, joista on tulkittavissa tviittaajan asettuminen jommankumman pelaavan joukkueen puolelle ja/tai toista joukkuetta vastaan. Tviittejä tulkittiin aineistosta selvää kannustusta (kannustaa, tsempata, sympata) ja emotionaalista tai affektiivista suhtautumista (toivoa, haluta, rakastaa, pelätä) osoittavien verbien perusteella sekä fyysistä asettumista osoittavien ilmausten (olla puolella/kelkassa/bandwagonissa) perusteella. Lisäksi erilaiset huudahdukset, emojit ja hashtagit (\#thatsthewayilikeit, \#CAMA) tarjosivat vihjeitä puolen valitsemisesta. Kaikki fanipositioiksi luokitellut tviitit on tulkittu suhteessa kontekstiinsa. Tarkemman analyysin välineenä hyödynnän diskursiivisen position käsitettä, jolla tarkoitan puhujan asettumista tiettyyn asemaan suhteessa keskustelunaiheeseen ja keskustelukumppaneihin.

\section{Yleisön asettuminen fanipositioihin}

Alustavan sisällönanalyysin perusteella fanipaikkoihin asettuminen näyttäytyy karkeasti jaoteltuna kahdella tavalla. Ensinnäkin tviittaava yleisö tuottaa itselleen faniposition hyvin eksplisiittisesti tuomalla selkeästi esille itsensä tekijänä (kannustan, hyppään Saksan kelkkaan) tai olijana (olen Kolumbian äijä, nyt ollaan Mehikon bandwagonissa). Toisaalta tviittaaja voi tuottaa oman fanipaikkansa myös varsin implisiittisesti, jolloin hän häivyttää itsensä ja korostaa sen sijaan joukkueita ja pelitilannetta (Tylyä dominointia \#kiitossaksa, sIIIIIITÄÄÄÄÄ!!!!).

Eniten fanipositiotviittejä esiintyy luonnollisesti ottelun aikana, jolloin tviittaaja seuraa ja kommentoi kannattamansa joukkueen otteita. Suurin osa ottelun aikana tuotetuista tviiteistä osuu ottelun kohokohtiin, etenkin maalien yhteyteen. Tarkastelen seuraavissa analyysiluvuissa fanipositioihin asettumista tarkemmin fani- ja yleisötutkimuksen näkökulmasta. Tarkastelen sekä tviittejä että televisiolähetystä affektiivi- 
suuden ja reaaliaikaisuuden akseleille syntyneenä virtuaalisena olohuoneena, aktiivisuuden ja julkisuuden synnyttämänä performatiivisena näyttämönä ja sosiaalisuuden ja interaktiivisuuden ulottuvuuksia yhdistävänä pseudoyhteisönä. Nämä kolme pääteemaa ovat syntyneet aineistostani nousseiden eksplisiittisen ja implisiittisen positiointitavan sekä aiempien sosiaalisen television tutkimuksen ja fanitutkimuksen vuoropuhelussa. Implisiittisesti tuotetut fanipositiot sijoittuvat pääosin virtuaalisen olohuoneen ulottuvuuteen ja eksplisiittiset performatiivisen näyttämön ulottuvuuteen. Pseudoyhteisön näkökulmasta faniutta tuotetaan sekä eksplisiittisesti että implisiittisesti.

\section{Fanipositiot virtuaalisessa olohuoneessa}

Virtuaalisessa olohuoneessa fanipositiot tuotetaan erilaisina affektiivisina reaktioina ja ne sijoittuvat useimmiten ottelun kohokohtiin, etenkin maalien yhteyteen. Ne ovat usein lyhyitä huudahduksia tai erilaisia emojeita, joiden kautta tuotetaan kannatuskohde. Esimerkissä tviittaajan fanipositio Kolumbian puolella tulee näkyviin välittömänä vastauksena Kolumbian maaliin.

\section{Goooooooool!!! \#colombia \#ylemmfutis (Kolumbia-Norsunluurannikko)}

Esimerkissä on nähtävissä, miten tviittaaja tuottaa fanipaikkansa luonnollisen näköisenä reaktiona lähetyksen tapahtumiin. Tyypillistä reagoinnille on esimerkin kaltainen "selostajamainen" huuto, joka tuotetaan usein pelaavan maan kielellä. Jalkapalloyleisön reagointia tutkineen Cornelia Gerhardtin (2006, 142-143) mukaan medioituun jalkapallo-otteluun reagoidaan varsin emotionaalisesti, mikä näkyy etenkin äänenvoimakkuuden nousuna ja erilaisina eleinä ja ilmeinä. Twitterin kautta "äänenvoimakkuuden nousu" tuotetaan esimerkin tapaan huutomerkein tai isoin kirjaimin, erilaiset tunnetilat puolestaan näyttäytyvät usein erilaisina hymiöinä.

Reaktio kehystetään usein esimerkin tapaan teemoittavalla hashtagilla (\#colombia), jonka kautta myös lähetystä seuraamaton tietää heti kumpi joukkue on tehnyt maalin. Alonson ja Shiellsin $(2013,1044)$ mukaan pelkästään Twitteriä seuraamalla ottelun kulusta voikin saada erittäin yksityiskohtaisen kuvan. Gerhardt $(2006,132)$ on kiinnittänyt huomiota myös siihen, miten jalkapallokatsoja puhuttelee kentällä olevia joukkueita ja niiden pelaajia kannustaakseen heitä. Tällaista parasosiaalista puhuttelua tuotetaan myös virtuaalisesti.

Edes vähän ammattiylpeyttä Brassit hei. Kamoon nyt. \#ylemmfutis \#mmfutis (BrasiliaSaksa)

Esimerkissä tviittaaja puhuttelee Brasilian joukkuetta eräänlaisesta tsemppaajan tai virtuaalisen valmentajan positiosta. Aineistossani joukkueita myös kannustetaan suoraan "huutamalla" televisiolle, mikä osoittautui varsin yleiseksi käytännöksi myös Highfieldin $(2013,254)$ tutkimien Tour de Francen livetviittaajien keskuudessa. Fani- 
positiot tuotetaan useimmiten implisiittisesti, ikään kuin luonnollisina paikkoina, joihin asettumista ei tarvitse perustella tai oikeuttaa. Virtuaalisessa olohuoneessa tuotetuille fanipositioille tunnusomaista onkin itsen ja oman tekemisen häivyttäminen. Käsitettä hieman venyttämällä myös seuraavan esimerkin kaltaiset eksplisiittisemmät fanipaikat voisi kuitenkin nähdä tuottavan suoraa reagointia mediatekstiin.

Kolumbialaiskannattajien fanitus on suorastaan mukaansa tempaavaa! Itsekin hypin täällä sohvalla ja huudan!! \#ylemmfutis \#COLvsCIV \#mmkisat (Kolumbia-Norsunluurannikko)

Gerhardtin $(2012,71)$ mukaan reagointia television tapahtumiin osoitetaan paitsi verbaalisesti, myös erilaisin ruumiillisin elein. Esimerkkiä voisikin siten tarkastella ruumiillisen reaktion kielellisenä esiintuomisena. Näin jalkapalloon liittyvät nonverbaaliset fanikäytännöt (hyppiminen ja huutaminen) tuodaan tviittiin muotoiltuna reagointina, joita kuitenkin käsittelen tarkemmin faniuden performansseina.

\section{Fanipositiot performatiivisella näyttämöllä}

Performatiivisella näyttämöllä fanipositiot näyttäytyvät tietynlaisina faniuden esityksinä, joille tyypillistä on erilaisten aktien tuottaminen metadiskursiivisesti. Kuten performanssia yleensäkin, myös näitä leimaa vahva itserefleksiivisyys ja mediatietoisuus (Rowe \& Baker 2012, 314). Performoitu fanipaikka tuotetaan eksplisiittisesti ja korostetusti: se nähdään usein valmiina fyysisenä asemana, mikä tulee näkyviin dynaamisten materiaalisten prosessien ja paikallissijojen runsaana käyttönä. Eksplisiittiselle positiointitavalle tyypillistä on erityisen runsas deiktisten elementtien käyttö. Deiktisillä elementeillä tarkoitan sellaisia kielen aineksia, joiden tehtävänä on liittää ilmaus puhehetken kontekstiin (VISK § 1423), kuten seuraavassa esimerkissä.

Andres Escobarin muistoa kunnioittaen mennään Kolumbian kelkassa tänään. \#mmfutis \#ylemmfutis (Uruguay-Kolumbia)

Esimerkissä deiktisen adverbin tänään käyttö sitoo tviitin puhetilanteeseen. Vaikka esimerkissä ei korosteta performatiiviselle esittämistavalle tyypillistä minätekijää, on oman position esiintuominen varsin eksplisiittistä. Kolumbian kelkassa oleminen asettaa tviittaajan performatiivisesti Kolumbian puolelle. Esittämällä perusteeksi fanipaikalleen Escobarin muiston kunnioittamisen tviittaajaa identifioi itsensä samalla sellaiseen globaaliin jalkapallofanien kategoriaan, joka rakentuu yhteisten jalkapallomuistojen ympärille. Tviittaajat asettuvat fanipositioihin myös emotionaalisesti, jolloin korostetaan minätekijän mentaalisia tiloja fyysisen asettumisen sijaan.

Faniuden performanssia tuotetaan usein erilaisiin fanikäytäntöihin kiinnitettynä. Se esitetään joko affektiivisina fanitekoina, kuten aiemmassa esimerkissä hyppimi- 
senä ja huutamisena, tai se voidaan sitoa tiettyihin ulkoisiin faniuden symboleihin, kuten esimerkissä.

Saksan pelipaita päällä. Check. Saksanlippu käden ulottuvilla. Check. Jännitys huipussa. Check. Nyt ollaan valmiita matsiin! \#ylemmfutis (Brasilia-Saksa)

Tviittaaja tuottaa kommentissaan itselleen Saksa-fanin position performatiivisen fanikuvauksen kautta. Katsoja esittää tviitissään eräänlaisen "fanin muistilistan", jonka avulla hän osoittaa tuntevansa otteluun valmistautumisen fanikäytännöt. Listan perusteella fanin on tärkeä tunnustaa väriä erilaisilla fanisymboleilla, mutta myös emotionaalinen latautuminen kuuluu ottelun ennakkorituaaleihin. Toistuva checksanan käyttö ohjaa tulkintaan, jossa tviittaaja ikään kuin tarkastaa omat fanikykynsä ja läpäisee itselleen asettaman fanitestin.

Toisin kuin livereagointina tapahtuvassa positioinnissa, eksplisiittiselle positiointitavalle tyypillistä on faniuden perustelu ja oikeuttaminen. Vaikka kansallisuus nähdään usein "luonnollisena" puolen valinnan kriteerinä (Heinonen 2005, 19), luettelee Raney $(2006,341)$ lisäksi lukuisia muita mahdollisia perusteita joukkueen kannattamiseen. Fanipaikkaan ei siten asetutakaan samalla tavalla luonnollisesti kuin silloin, jos Suomi pelaisi. Tviittaajat perustelevat ottamiaan fanipositioita muun muassa ennakkoasetelmilla, vedonlyönnillä, pelitavoilla, pelaavan joukkueen maantieteellisellä tai kulttuurisella läheisyydellä, mutta myös irrationaalisimmilla syillä kuten pelipaidan värillä tai huvittavan nimen perusteella. Seuraavassa esimerkissä on nähtävissä "väärän" puolen valinnan oikeuttaminen.

Välierissä en tule pitämään eurooppalaisten puolia, koska \#BRA \#ARG olisi \#kaikkienaikojenkiimaisinfinaali \#mmfutis \#ylemmfutis (Brasilia-Saksa)

Esimerkissä tviittaja asettuu eurooppalaisia joukkueita vastaan, mikä näyttää tviitissä eräänlaiselta normirikkomukselta. Tätä normirikkomusta tviittaja perustelee \#kaikkienaikojenkiimaisinfinaali -hashtagilla, joka vaatii performoidun tviitin yleisöltä tietynlaista jalkapallotuntemusta (ja -näkökulmaa). Tviittaajan perustelema oikeutus on siten uskottava vain niille katsojille, jotka jakavat tviittajan näkemyksen Argentiinan ja Brasilian kohtaamisesta klassikko-otteluna.

Kenties eksplisiittisin tapa tuottaa tietty fanipaikka on nimetä itsensä joukkueen faniksi tai kannattajaksi. Tällöin tviittaja pyrkii suorittamaan identiteettiään tekemällä selvän eronteon fanin ja ei-fanin välille. Fani-identiteettiä hyödynnetään aineistossa kuitenkin usein muihin tarkoituksiin kuin itse faniuden korostamiseen. Se toimii tarkastelupisteenä, josta nähtyä tapahtumaa merkityksellistetään. Sen kautta on mahdollista tuottaa toinen, usein ristiriitainen positio, irrottautumatta suhteellisen pysyvästä fani-identiteetistä. Fani- ja kannattaja-nimityksiä hyödynnetään aineistossa usein myös faniudesta irrottautumiseen kieltämällä fanius. Näin tviittaajalla on mahdollisuus ottaa kriittistä etäisyyttä tapahtumaan. 
Klose tuo kyllä hymyn huulille vaikka en Saksa fani olekkaan. \#mmfutis \#ylemmfutis (Brasilia-Saksa)

Esimerkissä tviittaaja tuo esiin mielipiteensä Saksan paidassa MM-historiaa tehneestä hyökkääjästä ja ikään kuin oikeuttaa sanomansa irrottautumalla Saksa-faniudesta. Näin tehdessään hän ottaa kriittistä etäisyyttä tapahtumaan. Tyypillisimmin fani-nimityksellä kuitenkin viitataan paikan päällä olevaan yleisöön.

symppaan algeriaa koska näyttää olevan faneille niin iso asia, voi raukkoja jos tulis häviö \#mmfutis \#ylemmfutis (Algeria-Venäjä)

Esimerkissä tv-ruudulla näkyvät Algeria-fanit toimivat tviittaajan perusteluna omalle fanipositiolleen. Lähetyksessä performatiivisesti esiintyvät fanit ovatkin usein tviittaajien kommentoinnin kohteena. Tviittaajat sekä ihailevat että tuomitsevat fanien toimintaa, jolloin he itse asettuvat korostetusti mediaspektaakkelin yleisöksi varsinaisen jalkapallo-ottelun sijaan.

Eksplisiittinen ja performatiivinen positiointi tuottaa usein tilapäistä trendifaniutta. Puolen valitseminen koetaan jalkapallo-ottelun viihdyttävyyden kannalta oleellisena, jopa välttämättömänä kriteerinä. Fanipaikka on hetkellinen tila, josta irrottaudutaan yleensä nopeasti. Jalkapallon MM-kisojen livetviittaajalle ominaista onkin, että kannatuskohde voi vaihdella useaan kertaan turnauksen aikana, jopa yhden ottelun sisällä. Eksplisiittinen positiointi on tyypillisintä ennen ottelun alkua, jolloin katsoja osoittaa otteluun valmistautumisen rituaalejaan tai tekee tietoisesti valinnan siitä, kumman joukkueen näkökulmasta alkaa ottelua seurata.

Ottelun viihdyttävyyteen kuuluu Raneyn (2006, 343-344) mukaan tietynlainen otteluun valmistautuminen, joukkueen ja itsen psyykkaaminen, johon kaikessa medioidussa urheilupuheessa liitetään usein erilaisia väkivaltaisia elementtejä. Kutsun tällaista psyykkauspuhetta faniuhoksi. Faniuhoaminen on tyypillisintä esimerkin tavoin ennen varsinaisen ottelun alkua.

Samba on kaunis tanssi, varsinkin kun sitä tehdään nurmikolla meetwursteja maahan polkien. \#ylemmfutis (Brasilia-Saksa)

Esimerkissä tviittaaja häivyttää itsensä ja oman positionsa passiivirakenteen avulla. Fanipositio onkin luettavissa vasta kontekstista. Ensinnäkin \#ylemmfutis toimii tviitissä kontekstualisoivana topikaalisena elementtinä, joka sitoo kielikuvan ottelutapahtumaan. Tviittaajan oma positio on lisäksi tulkittavissa fanipositioksi vasta laajemman kulttuurisen kontekstin kautta: samba assosioituu brasilialaiseen kulttuuriin, meetwurstit saksalaiseen. Toiminnan kuvaileminen metaforisesti maahan polkemiseksi ei jätä sijaa epäilyksille: tviittaaja uskoo Brasilian voittavan Saksan ylivoimaisesti. Näen tviitin tuottavan tietynlaisen faniuden performanssin etenkin sen suunnitellun muodon vuoksi, vaikka se ei toimikaan samalla tavalla performatiivisena aktina kuin eksplisiittiseen fanipositioon asettuminen. 


\section{Fanipositiot pseudoyhteisössä}

Yleisö asettuu usein jalkapallokatsomisen konventioiden mukaisiin valmiisiin roolipositioihin (toisen pelaavan joukkueen puolelle), vaikka tarjolla ei ole suomalaiskatsojalle luonnollista fanipaikkaa. Schirra ym. $(2014,2446)$ korostavat draamasarjan livetviittajien motiiveja käsittelevässä tutkimuksessaan, että yksi tärkeimmistä kannustimista tviittaamiseen ohjelman aikana on katsojien halu tuntea kuuluvansa johonkin yhteisöön. Myös omassa aineistossani on nähtävissä tällaista pseudoyhteisöön tukeutumista silloin, kun tavoitellaan jonkinlaista yhteistä fanipaikkaa.

Yhteisen fanipaikan tavoite tulee esille etenkin Twitterin pseudoyhteisön (para-) sosiaalisena puhutteluna, jossa tviittaaja kääntyy muiden livetviittaajien puoleen valitessaan kannatuskohdettaan. Tviittaaja saattaa kutsua muita katsojia tietystä fanipositiosta käsin liittymään samalle puolelle tai tiedustella suoraan gallupmaisesti kummalla puolelle muu yleisö ottelussa on. Seuraavassa esimerkissä on nähtävissä tviittajan halu identifiotua yhteisöön.

\section{Oonks ainoo joka on Kamerunin puolella? \#mmfutis \#ylemmfutis (Meksiko-Kamerun)}

Katsoja pyrkii tviitissään yhteisölliseen fanipaikkaan esittämällä suoran kysymyksen muille livetviittajille. Tviittaaja näyttää kokevan oman positionsa marginaaliseksi \#ylemmfutis- ja/tai \#mmfutis-pseudoyhteisössä. Monikon ensimmäisellä persoonapronominilla livetviittaaja voi liittää itsensä laajempaan faniyhteisöön (me Saksafanit) tai neuvotella yhteisöllistä fanipaikkaansa muiden livetviittajien kanssa tuottamalla katsojille yhteisen kategorian, kuten esimerkissä.

No, on vaan ihan vähän eurooppaa RT @JussiMKorhonen: Eikö se siis niin mene, että me kannatetaan Eurooppaa eli Venäjää? \#ylemmfutis (Algeria-Venäjä)

Esimerkissä on nähtävissä tviittajien välinen neuvottelu fanipaikasta. Tviittaaja $A$ on esittänyt kysymyksen, johon tviittaaja $B$ vastaa liittämällä $A: n$ alkuperäisen viestin osaksi omaa tviittiään uudelleentviittaus-toiminnon avulla. Tviittaaja A pyrkii tuottamaan pseudoyhteisölle yhteisöllistä fanipaikkaa ja esittää (vakavissaan tai humoristisesti) ikään kuin varmistuskysymyksen, jossa haluaa selvyyden siitä, tuleeko meidän kannattaa Venäjää. Me viittaa tviitissä suomalaiseen yleisöön, jonka normatiivisena velvollisuutena on tviitin perusteella kannustaa kisoissa eurooppalaista joukkuetta. Tviittaaja B hyväksyy A:n näkemyksen eurooppalaisen joukkueen kannattamisen velvollisuudesta, mutta irrottautuu sen tarjoamasta yhteisöllisestä fanipaikasta, koska ei näe Venäjää eurooppalaisena joukkueena. Aineistossani mepronominin käyttö yhteisen fanipaikan osoittimena on kokonaisuudessaan kuitenkin varsin vähäistä. Useimmiten me-muotoon kirjoitetut tviitit tuottavat eksklusiivisen me-ryhmän, joka rajaa meidät pitämään sisällään ainoastaan tviittaajan ja hänen todelliset kanssakatsojansa. Sen sijaan implisiittisesti tuotettu, luonnollistettu fanius tuottaa joissain tapauksissa yhteisölliseen fanipaikkaan pyrkivää posi- 
tiointia. Esimerkissä kollektiivinen fanipositio tuotetaan passiivirakenteen ja evaluoinnin kautta.

Olispa hienoo jos saatais kaks eurooppalaista joukkuetta finaaliin! \#ylemmfutis (Brasilia-Saksa)

Passiivirakenne viittaa tviitissä meihin sisäryhmänä, vaikkei se näyttäydykään selvärajaisena kategoriana. Viittattiin tviitissä sitten suomalaisiin jalkapallokatsojiin, livetviittaajiin tai kaikkiin eurooppalaisiin, näyttää eurooppalaisen joukkueen puolelle asettuminen luonnolliselta yhteiseltä fanipositiolta. Eurooppalaisen joukkueen kannattamista ei tarvitsekaan perustella samalla tavalla kuin siitä irrottautumista. Tällainen perustelemattomuus implikoi Heikkisen $(1999,92)$ mukaan tietynlaisia ideologisia merkityksiä, esimerkiksi näkemyksiä vallassa olevista identiteettimäärityksistä, jotka tuotetaan itsestäänselvinä.

\section{Televisiolähetyksen roolit sosiaalisessa televisiossa}

Tässä analyysiluvussa sosiaalisen television ulottuvuuksia tarkastellaan televisiolähetyksen näkökulmasta.

\section{Yle virtuaalisena olohuoneena}

Ylen tarkasteleminen virtuaalisena olohuoneena nostaa keskiöön reaaliaikaisuuden ja siten jaetun katsojuuden. Virallisen hashtagin käyttö tarjoaa yleisölle mahdollisuuden myötäelää jalkapallo-ottelua varsin autenttisesti: liittämällä hashtagin tviittiinsä tviittaaja kontekstualisoi sen liittymään television senhetkisiin tapahtumiin. Koska yleisö elää virtuaalisessa olohuoneessa lähetyksen rytmissä, määrittää televisiolähetys siten edelleen hyvin pitkälti sitä, mistä sosiaalisen median kanavissa puhutaan. Yle virtuaalisena olohuoneena näyttäytyy tästä perspektiivistä varsin välittömänä kanavana sitoutua mediatekstiin.

Ylen lähettämää mediaspektaakkelia voidaan pitää Couldryn (2005) termein jaettuna mediarituaalina, jonka ympärillä katsojat haluavat tuntea kuuluvansa osaksi yhteistä katsomiskokemusta. Ylen tarjoaman virallisen hashtagin kautta katsojat voivat lisäksi täydentää katsomiskokemustaan keskustelemalla muiden katsojien kanssa ja reagoimalla mediatekstiin reaaliaikaisesti, ikään kuin he istuisivat samalla sohvalla yhteisen television ääressä. Myös Ylen studioisännät liittyvät usein jaetun mediarituaalin yleisöön.

Klinga: Todistimme varmaan yhtä MM-historian eriskummallisinta puoliaikaa. Isäntämaa Brasilia VIISI-NOLLA tappiolla Saksaa vastaan. Ato, miten tää on mahdollista? (Brasilia-Saksa) 
Esimerkissä studioisäntä Ville Klinga asettuu osaksi ennakoimattoman mediaspektaakkelin yleisöä tuottaessaan puheenvuoronsa monikon ensimmäisessä persoonassa. Käyttäessään todistaa-verbiä, hän asettaa televisiokatsojat silminnäkijöiksi ja korostaa siten lähetyksen luomaa jaettua tässä ja nyt -kokemusta. Myös kysymys asiantuntijalle esitetään ikään kuin yhteisesti koko mediarituaalin yleisön suusta: asiantuntijan tehtävänä on selittää tapahtuma "meille kaikille".

\section{Yle performatiivisena näyttämönä}

Jos fanipositioihin asettuvat tviittajat toimivat faniuden performanssin esiintyjinä, on Ylen lähetyksen rooli puolestaan tarjota noille esityksille fyysiset puitteet, toisin sanoen näyttämön. Tällaisena näyttämönä voi pitää TV-ruudun alalaitaan studiokeskustelun aikana ilmestyvää palkkia, jossa pyörii katsojien virallisella hashtagillä varustettuja tviittejä. Tviittaamiseen kannustetaan jatkuvasti pitkin kisoja.

Sipilä: Ja myös totta kai sosiaalinen media on vahvasti läsnä tässä ottelussa ja voitte osallistua tämänkin lähetyksen tekemiseen monella tapaa niin Facebookissa, Instagramissa kuin sitten myös Twitterin puolella hashtagillä ylemmfutis ja päivän päätteeksi jälleen palkitsemme parhaan tviitin (Algeria-Venäjä)

Esimerkki on tyypillinen studioisännän puheenvuoro mediaspektaakkelin yleisölle, jossa hän rohkaisee yleisöä käyttämään ohjelman virallista hashtagiä. Puheenvuoro antaa kuvan aktiivisesta yleisöstä, jonka toiminnalla on vaikutusta lähetyksen etenemiseen ja muotoutumiseen. Potentiaalinen vaikuttaminen ja osallistuminen kietoutuvat nähdäkseni eritoten performanssin julkisuuden aspektiin: osallistumalla hashtagvirtaan katsojalla on mahdollisuus saada tviittinsä julkiseksi myös tv-ruudulla. Sekä julkisuus että mahdollinen palkinto kannustavat katsojia muotoilemaan tviittinsä hauskaan tai erityisen nasevaan ulkoasuun.

Ylen rooli perfomatiivisena näyttämönä tulee näkyviin myös tietynlaisen ideaalifanin mallin tarjoamisena. TV-ruudulla näkyvät fanijoukot karnevaalihenkisine rekvisiittoineen ja suurine tunteineen tuottaa ideaalifanin mallin, johon katsojaa kutsutaan identifioitumaan (Kolamo 2014: 216). Toisin sanoen lähetys luo tietynlaisen fanikuvaston, joka antaa ohjeita siihen, miten fania "esitetään". Kuvakaappaus Kolumbian ja Uruguayn välisestä ottelusta on tyypillinen esimerkki kameran löytämistä performatiivisesti esiintyvistä faneista. 


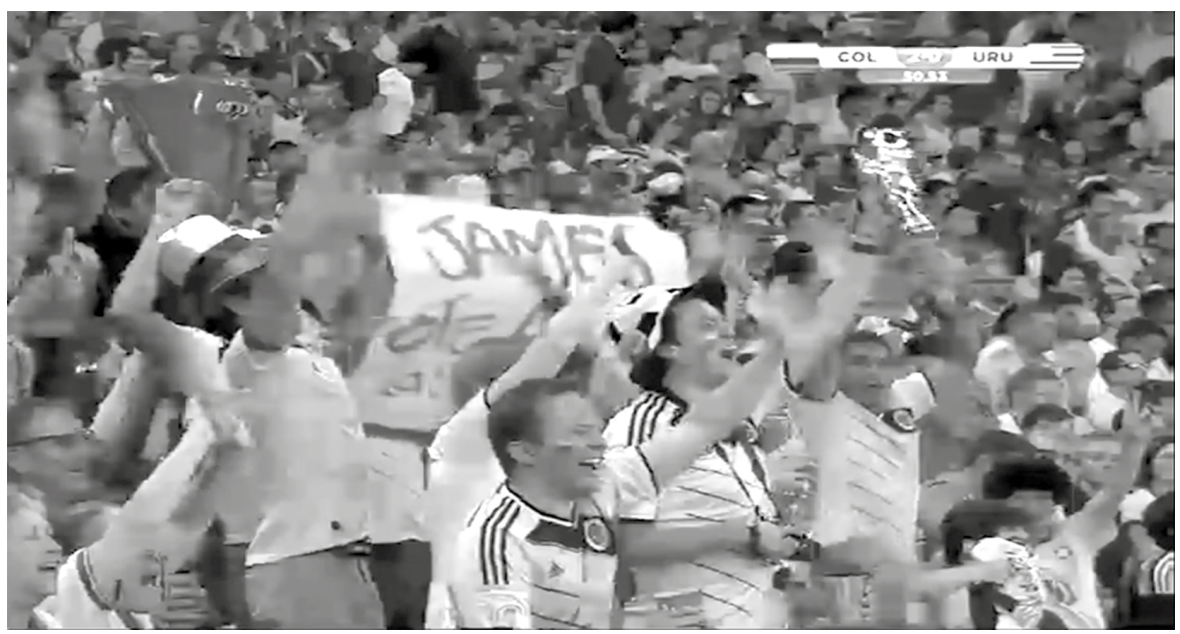

Kuva 1. Kolumbian fanijoukko juhlimassa Kolumbian toista maalia Uruguayta vastaan. (Kolumbia-Uruguay)

Kuvassa on nähtävissä ideaalifanin mallille tunnusomaisesti sekä lukematon määrä erilaista väriä tunnustavaa fanirekvisiittaa että kannattajien emotionaalinen ja sosiaalinen panostus joukkueeseensa. Ottelun selostaja kommentoi usein fanien ulkonäköä tai toimintaa silloin, kun kamera valitsee fanijoukon kuvaan. Toisaalta selostaja tulkitsee silloin tällöin fanien toimintaa myös kameran ulkopuolelta. Tällöin hän laajentaa yleisön näkökenttää ja tuottaa ideaalifanin mallia omista tulkinnoistaan. Huomioitavaa on, että kamera ei huomioi lainkaan "väärinkannattajia". Selostaja sen sijaan saattaa tehdä arvottavia huomioita ideaalifanin mallin vastaisesti käyttäytyvistä kannattajista, kuten alla olevasta esimerkistä on nähtävissä.

Litmanen: nyt vihelletään kun hän koskee palloon Juusela: joo se on aivan uskomaton tilanne kotistadionilla Litmanen: lähtökohta jos kerran päätetään viheltää ni silloin pitäis viheltää joka kerta ku brasilialaisel on pallo et kyl tää kollektiivinen heikkous tänään on ollu (Brasilia-Saksa)

Esimerkissä selostaja Niki Juusela ja asiantuntijakommentaattori Jari Litmanen tuomitsevat brasilialaisyleisön buuaukset, jotka on osoitettu yleisön silmätikuksi joutuneelle brasilialaishyökkääjä Fredille. Yleisön vihellykset välittyvät kameran kautta kotikatsojille, mutta vasta selostajien kommentit tekevät niistä merkityksellisiä. Esimerkissä tilanne tulkitaan televisioyleisön puolesta ja arvotetaan tuomittavaksi fanikäytökseksi. Litmanen esittää vielä esimerkin toisessa kommenttiosassaan, miten ideaalifanin tulisi toimia. Näin studio puuttuu kameran välittämän ideaalifanin mallin rakentamiseen ja pyrkii viemään sitä omalla arvioinnillaan oikeaan suuntaan. Tämän yleisön käytöksen tuomitsemisen jälkeen myös livetviittaajat tuottivat samansuuntaisia näkemyksiä brasilialaisfanien "väärinkannattamisesta". 
Tulkitsen televisiolähetykseen liittyvien sosiaalisten ja konventionaalisten roolien kuuluvan sosiaalisen television performatiivisen näyttämön ulottuvuuteen, sillä katson Papacharissin $(2012,1990)$ tavoin suhteellisen vakiintuneiden roolien olevan toiston kautta performatiivisesti tuotettuja konstruktioita. Studiossa asiantuntijavieraiden ja otteluennakoiden tehtävänä on eräänlainen "jalkapallokielen tulkkaaminen", pelin tekeminen ymmärrettäväksi katsojalle. Tyypillisesti tulkkaamisen yhteydessä korostetaan jalkapalloon liittyvää luonnollista vastakkainasettelua ja pyritään siten kannustamaan yleisöä puolen valintaan.

Pohja: no joo tää on tietysti kärjistys mutta hurmosjalkapallo keltanen meri katsomossa huutaa ja niin kauan ku jaksaa niin painetaan ja toisella puolella on taas huomattavasti enemmän mun mielestä systemaattisuutta ja suunnitelmallisuutta (Brasilia-Saksa)

Esimerkissä Antti Pohja esittelee asiantuntijoiden laatimia tärppejä Brasilian ja Saksan väliseen välieräotteluun. Yhdeksi ottelun ratkaisukohdaksi asiantuntijat ovat listanneet tunne vs. systeemi -kohdan, jota Pohja perustelee ja avaa yleisölle esimerkissä. Hän tuottaa vastakkainasettelun stereotyyppisten kuvausten kautta, jossa brasilialaiset nähdään tunnepelaajina, saksalaisjoukkuetta kuvataan rationaaliseksi pelitapansa noudattajaksi. Vastakkainasettelujen luominen onkin Raneyn $(2006,344)$ mukaan mediaurheilussa erityisesti asiantuntijoiden ja kommentaattorien tehtävänä. Aineistoni perusteella yleisö ottaa asiantuntijoiden tarjoaman tiedon vastaan ikään kuin apuna valita kannatuskohteensa otteluun. Tämä on nähtävissä eri tavoin alla olevista tviiteistä.

"Systemaattisuutta ja suunnitelmallisuutta" - Just my kind of a team :) \#aneuerseite \#BRAGER \#ylemmfutis (Brasilia-Saksa)

\#ylemmfutis Jakolinja Teho vs. Tunne. Näistä pitäis amatöörin valita? Sorry: Aion vain NAUTTIA hienosta pelistä. (Brasilia-Saksa)

Ensimmäisessä esimerkissä on nähtävissä tviittaajan tuottama Saksa-fanin positio, joka on tuotettu studion rakentamien kärjistysten pohjalta. Katsoja toistaa tviitissään studion tekemän näkemyksen Saksan joukkueesta sanatarkasti lainausmerkein ja osoittaa sitten omassa puheessaan, että sellaisen joukkueen puolella haluaa ottelussa olla. Toisessa esimerkissä sen sijaan on nähtävissä tviittajan tyytymättömyys studion tuottamiin mahdollisiin fanipositioihin. Tviittaaja tuottaa deonttisen modaaliverbin konditionaalimuodon pitäisi avulla kannatuskohteen valinnan eräänlaisena normipositiona, johon ei halua tai osaa asettua. Tviittaaja kieltäytyykin studion tarjoamista fanipaikoista tuottamalla itselleen puolueettoman katsojan paikan.

Tutkimukseni perusteella jalkapalloon liittyvä ydinkysymys (kumpi voittaa ottelun?) (Kolamo 2014, 202) jakaantuu ikään kuin kahtia studion ja yleisön välillä. Studion tehtävänä on vastata kysymykseen kumman uskot voittavan?, yleisön kumman toivot 
voittavan?. Studiossa kysymys on usein esitetty eksplisiittisesti suoraan asiantuntijavieraille, joilta myös odotetaan asiantuntevia perusteluja odotuksilleen. Alla on nähtävissä tästä normista poikkeaminen.

Pohja: Joo samaa mieltä, emmä, mä en osaa sanoa kyllä yhtään et kumpi on ennakkosuosikki tänään. Koitin koko päivän sitä pohtia et sanoisin tässä sen sitte mut en pysty että aluks oli vähän niin ku et Kolumbia vois olla se mut et ehkä sit kuitenkin täytyy nostaa ihan niin ku Norsunluurannikko siihen vierelle et mä en mä en rupee veikkailee et kumpi rupee pelii viemään tai muuta (Kolumbia-Norsunluurannikko)

Esimerkissä Pohja osoittaa oman roolinsa asiantuntijana, jonka tehtäviin kuuluu ennakkosuosikin valinta ja sen perustelu. Pohja tuo tämän roolin näkyväksi ilmaisemalla kyvyttömyytensä asettua sen vaatimiin odotuksiin. Kun hän sanoo, ettei rupee veikkailee, hän implikoi asiantuntijan roolikonventioihin kuuluvan ottelun ennakoinnin tietona, ei arvailuna. Gerhardtin $(2006,143)$ mukaan asiantuntijana olemisen kriteerinä onkin nimenomaan tieto vastakohtana tunteille, joka puolestaan on fanin ominaisuus. Yleisölle kysymystä kumman toivot voittavan? ei esitetä suoraan, mutta se on implisiittisesti luettavissa joistakin studio-osuuksista ja etenkin yleisön lähettämistä tviiteistä. Suorimmin yleisöä kehotettiin puolen valitsemiseen kisojen alussa, jolloin katsojille tarjottiin mahdollisuus testata Ylen nettisivujen kautta toimivan fanikoneen kautta, mitä joukkuetta heidän kannattaisi kisojen aikana kannattaa. Implisiittisemmin puolen valintaan kannustetaan esittelemilläni vastakkainasettelujen keinoilla. Alla olevan esimerkin tapaan yleisön tviiteissä toive ottelun voittajasta tuodaan usein ilmi eksplisiittisesti, ikään kuin vastauksena jollekin.

Kisoja edeltäneen veikkaukseni finalistit BRA-ARG. Toivon siis sitä. Illan filiksillä laitan silti BRA 1-3 GER. \#mmfutis \#ylemmfutis \#lihis (Brasilia-Saksa)

Esimerkissä tviittaja tuottaa itselleen kaksi erilaista, mutta samanaikaista vedonlyöjän positiota: hän esittää tviitissään itselleen "tämän hetken vedonlyöjän" position, jossa hän tuottaa veikkauksen ottelun voittajasta. Oleellisempi on kuitenkin "menneisyyden vedonlyöjän" positio, jonka kautta hän tuottaa eksplisiittisen toiveensa ottelun voittajasta.

Yleisölle puolen valitseminen näyttää olevan eräänlainen sosionormativiinen käytäntö, joka kuuluu ideaalikatsojan velvollisuuksiin. Puolen valitseminen koetaan ottelun jännittävyyden ja viihdyttävyyden kannalta usein välttämättömäksi. Sen sijaan studion puolueellisuus nähdään usein normirikkomuksena.

Voisiko sen brassien huoraamisen jo lopettaa ja siirtyä seuraavan ottelun alustamiseen, kiitos. \#ylemmfutis \#mmfutis (Kolumbia-Uruguay)

Esimerkissä tviittaja osoittaa turhautumisensa Brasilia-Chile-ottelun jälkikeskusteIuun, jossa asiantuntijat asettuvat tviittaajan mielestä liikaa Brasilian puolelle. Kolamo 
(2014, 213-214) osoittaakin omassa tutkimuksessaan jalkapallon MM-kisojen studiokeskusteluun liittyen, että asiantuntijoilta odotetaan tietyssä käsikirjoitetussa roolipositiossa pysymistä. Asiantuntijoille sallittu "fanipositio" näyttäisi kuitenkin olevan eräänlainen oikeudenjakajan positio, joka tuotetaan usein näennäisen objektiivisesti erilaisin arvioinnein. Tällainen moraalinen oikeutus on tunnusomaista jalkapallodraamassa (Kolamo 2014, 206), eikä se usein vaadi seurakseen perusteluja. Esimerkissä selostaja Kaj Kunnas esittää oikeutuksen kuitenkin varsin varauksellisesti.

Kunnas: ja jollakin lailla tuntuu hyvältä että Meksiko nyt sai tuon tehdä koska kun kaksi maalia vietiin niin (.) jollakin lailla (.) vaikka urheilussa mitään oikeusmaaleja ei jaellakaan niin siinä Oribe Peralta

Litmanen: joo on Meksiko täs ollu aktiivisempi koko pelin ajan ja tosiaan ne kaks hylättyy maalia ni jos nyt ajatellaan että ollaan jollain tavalla oikeudenmukasii (--) tai et ansaitsee (.) enemmän paikkoja ollu paremmat paikat (Meksiko-Kamerun)

Esimerkissä selostaja Kaj Kunnas ja asiantuntijakommentaattori Jari Litmanen neuvottelevat yhteistä oikeudenjakajan positiota. Meksikon maali tulkitaan ansaituksi, koska ensimmäisellä puoliajalla tuomari oli virheellisesti hylännyt kaksi joukkueen tekemää maalia. Lisäksi aktiivisuus nähdään esimerkin tapaan usein oikeutuksena joukkueen puolelle asettumiseen. Myös tviittaajat ottavat usein tällaisen "asiantuntijan faniposition" oikeuttamalla kannatuskohdettaan esittämällä erilaisia otteluun tai joukkueeseen liittyviä (pseudo)rationaalisia perusteita.

\section{Yle pseudoyhteisönä}

Sosiaalisuuden ja interaktiivisuuden elementit yhdistyvät pseudoyhteisössä, jollaisena Yle näyttäytyy pitkin kisojen. Se on tila, jossa kuviteltua yleisöä puhutellaan kuviteltuna suomalaisena tulkintayhteisönä. Lähetys ei tuota eksplisiittisesti suomalaiskatsojille yhteisiä fanipositioita, mutta se muodostaa näkyvän suomalaiskansallisen kehyksen, jonka kautta tapahtumia merkityksellistetään ja tulkitaan. Esimerkissä keskustellaan ottelun lähtökohdista ja pohditaan asetelmia Kolumbian ja Uruguayn väliseen otteluun.

Sipilä: Ja nyt suunnataan katseet sitten tuohon seuraavaan otteluun. Jos tämä oli iso peli Brasiliassa on se ihan sitä samaa sitten Kolumbiassa ja Uruguayssa. Onks meillä täällä Suomessa ees oikeesti mitään käsitystä siitä et kuinka isoista asioista noi pelaa tuolla? (Kolumbia-Uruguay)

Esimerkissä korostetaan meitä suomalaisia televisioidun jalkapallon katsojia vastakohtana jalkapallon suurmaina pidettyjen Etelä-Amerikan maiden fanaattisiin katsojiin. Usein varsin stereotyyppistenkin kuvausten kautta rakennetaan erilaisia (jalkapallo)identiteettejä suhteessa suomalaiseen kulttuuriin. 
Pseudoyhteisön ulottuvuuteen voidaan liittää myös jo aiemmin käsittelemäni ideaalifanin ja toisaalta mediarituaalin jaetun katsojuuden käsitteet. Molemmat leikkaavat kuvitellun yleisön ja yhteisön käsitteitä, jotka käsitän vahvasti pseudoyhteisön ja faniuden sosiaalisen elementin akselille. Oleellista tässä näkökulmassa on, että lähetys tuottaa tietynlaisen oletetun yleisön ja siten valmiita faniuden paikkoja, joista tviittajat voivat kuitenkin halutessaan välittömästi irrottautua.

\section{Lopuksi}

Sosiaalisen television kautta tuotettua mediaspektaakkeliin liittyvää faniutta leimaa hetkellisyys. Virtuaalisessa olohuoneessa medioidulle jalkapallokatsojuudelle tyypillisesti (Heinonen 2005, 67) tviittaaja sitoutuu ja panostaa emotionaalisesti joukkueeseen jännittävän katsomiskokemuksen toivossa, mutta vain irrottautuakseen siitä ottelun jälkeen ja valitakseen uuden kiinnittymiskohteen. Performatiivisella näyttämöllä katsoja puolestaan tarttuu faniuteen erilaisten julkisten fanikäytäntöjen kautta. Katsoja voi esittää fania kannustamalla pelaavia joukkueita tai osoittamalla otteluun liittyviä fanirituaalejaan, mutta "fanin rooliasu" on myös koska tahansa riisuttavissa. Pseudoyhteisössä livetviittaaja haluaa olla osa laajempaa yleisöä ja yhteisöä, mutta kuten muissakin sosiaalisen television ulottuvuuksissa, vain hetkellisesti. Katsojat eivät juuri käy suoraa dialogia toistensa kanssa, vaan kerääntyvät Ylen tarjoaman hashtagin ympärille tilapäiseksi \#ylemmfutis-yhteisöksi.

Nähdäkseni sosiaalinen televisio toimiikin tietynlaisen trendifaniuden (Nikunen 2005) tuottajana erityisen hyvin juuri hetkellisyytensä vuoksi. Trendifaniudelle tyypillisesti fanius koetaan kausiluonteisena prosessina, johon osallistuminen on sen saaman mediajulkisuuden vuoksi sosionormatiivinen käytäntö. Trendifanius valtavirtaistaa fanimaisina pidettyjä piirteitä, eikä mielekästä siten olekaan erotella spektaakkelin yleisöä faneihin ja katsojiin, vaan oleellista on yleisön näkeminen osallistujina, jotka tuottavat itselleen mielekkään katsomiskokemuksen asettumalla tilanteisesti tietynlaisiin fanimaisiin asemiin. Vaikka myös muiden sosiaalisen median ja verkon faniyhteisöjen puitteissa tällaisen trendifaniuden tuottaminen on mahdollista, kietoutuu livetviittaaminen vieläkin tiiviimmin reaaliaikaisuuden ja julkisuuden elementteihin.

Mediayhtiöt faniuttavat yleisöjään nimenomaan reaaliaikaisuuden ja julkisuuden sekä lisäksi interaktiivisuuden avulla. Sosiaalisen television kautta televisiolähetys tuottaa ikään kuin uudelleen jo kuolleeksi julistettua televisuualista lähetysvirtaa, johon osallistuakseen katsojan on oltava tietyllä hetkellä lähetyksen ääressä. Tviittien näyttäminen tv-ruudussa tekee osallistumisesta lisäksi julkista, jolloin livetviittaamisen houkuttelevuus ensisijaisena osallistumiskanavana kasvaa entisestään. Sosiaalisen television voi näin käsittää samanaikaisesti sekä välittömyyden että hypermediaalisuuden logiikkaan (Bolter \& Grusin 1999, 5) perustuvana mediana, joka yhtäältä häivyttää läsnäoloaan (virtuaalinen olohuone) ja toisaalta korostaa sen moninkertaisuutta (performatiivinen näyttämö). 
Tässä tutkimuksessa katseen kohdistaminen tviittien lisäksi lähetykseen avaa pääsyn siihen televisiolähetyksen ja tviittien verkostoon, jossa faniuden merkitykset neuvotellaan ja realisoidaan. Siten mielenkiintoista ei ole pelkästään se, mitä tviitataan tai mistä lähetyksessä puhutaan, vaan se, miten lähetys ja yleisö ovat vuorovaikutuksessa keskenään. Tviittajan tuottamat fanipositiot ovatkin usein tietynlaisia vastauksia televisiolähetykseen. Niiden kautta tviittaja osoittaa hyväksyvänsä lähetyksen tarjoamat roolit, näkemykset ja odotukset tai toisaalta irrottautuvansa niistä.

\section{Viitteet}

1 Kiitän Suomen Kulttuurirahastoa tutkimukseni tukemisesta.

2 Zimmerman (1998) käyttää positio-käsitteen sijaan termiä diskursiivinen identiteetti.

\section{Kirjallisuus}

Abercrombie, Nicholas \& Longhurst, Brian (1998). Audiences. A sociological theory of performance and imagination. London: SAGE.

Alonso, Omar \& Shiells, Kyle (2013). Timelines as summaries of popular scheduled events. WWW' 13 Companion Proceedings of the 22nd International Conference on World Wide Web, 1037-1044.

Anderson, Benedict (2006 [1983]). Imagined Communities. Reflections on the Origin and Spread of Nationalism. London: Verso.

Anstead, Nick \& O'Loughlin, Ben (2011). The Emerging Viewertariat and BBC Question Time: Television Debate and Real-Time Commenting Online. The International Journal of Press/Politics XX(X), 1-23.

Bennett, Lucy \& Booth, Paul (2015). Performance and performativity in fandom. Transformative Works and Cultures. 18. Saatavilla: http://journal.transformativeworks.org/index.php/twc/article/view/675/511 (luettu: 15.8.2016).

Bolter, Jay David \& Grusin, Richard (1999). Remediation. Understanding New Media. Cambridge: The MIT Press.

Booth, Paul (2010). Digital Fandom: New Media Studies. New York: Peter Lang.

Boren, Inger-Lise Kvalviknes \& Hickman, Jonathan (2013). Studying fan activities on Twitter: Reflections on methodological issues emerging from a case study on The West Wing fandom. First Monday 18: 9-2. Saatavilla: http://firstmonday.org/ojs/index.php/fm/article/view/4268/3740 (luettu 20.4.2016).

Couldry, Nick (2005). Media rituals. Beyond functionalism. Teoksessa: Rothenbuhler, Eric W. \& Coman, Mihai (toim.). Media Anthropology. London: Sage. 59-69.

D'Heer, Evelien \& Verdegem, Pieter (2015). What social media data mean for audience studies: a multidimensional investigation of Twitter use during a current affairs TV programme. Information, Communication Q Society. 18:2, 221-234

Davies, Bronwyn \& Rom Harré (1990). Positioning: The discursive production of selves. Journal for the Theory of Social Behaviours. 20:1, 43-63.

Deller, Ruth (2011). Twittering on. Audience research and participation using Twitter. Participations. 8:1, 216-245.

Eggins, Suzanne \& Martin J.R. (1997). Genres and registers of discourse. Teoksessa: van Dijk, Teun (toim.). Discourse as Structure and Process. Discourse Studies: A Multidisciplinary Introduction. London: SAGE. 230-256.

Fairclough, Norman (1997). Miten media puhuu. Tampere: Vastapaino.

Gerhardt, Cornelia (2006). Moving closer to audience. Watching football on television. Revista Alicantina de Estudios Ingleses. 19: 125-148.

Gerhardt, Cornelia (2012). Notability. The construction of current events in talk-in-interaction. Teoksessa: Ruth Aya $\beta$ \& Cornelia Gerhardt (toim.). The Appropriation of Media in Everyday Life. Amsterdam: John Benjamins Publishing Company. 47-78. 
Giglietto, Fabio \& Selva, Donatella (2014). Second screen and participation: A content analysis on a full season dataset of tweets. Journal of Communication. 64:2, 260-277.

Giulianotti, Richard (2002). Supporters, followers, fans and flaneurs. A taxonomy of spectator identities in football. Sport Q Social Issues. 26:1, 25-46.

Harrington, Stephen (2013). Tweeting about telly. Live TV, audiences and social media. Teoksessa: Weller, Katrin; Bruns, Axel; Burgess, Jean; Mahrt, Merja \& Puschmann, Cornelius (toim.). Twitter and Society. 237-248. New York: Peter Lang.

Harrington, Stephen; Highfield, Tim \& Bruns, Axel (2012). More than a backchannel. Twitter and Television. Participations. Journal of Audience Q Reception Studies. 10:1, 405-409.

Hautakangas, Mikko (2008). Yleisöä kaikki, tuottajia kaikki. Toimijuuden neuvotteluja Suomen Big Brotherissa. Teoksessa: Nikunen, Kaarina (toim.). Fanikirja. Tutkimuksia nykykulttuurin fani-ilmiöistä. Jyväskylä: Nykykulttuuri, 161-183.

Heikkinen, Vesa (1999). Ideologinen merkitys kriittisen tekstintutkimuksen teoriassa ja käytännössä. Helsinki: Suomalaisen kirjallisuuden seura.

Heikkinen, Vesa; Hiidenmaa, Pirjo \& Tiililä, Ulla (2000). Teksti työnä, virka kielenä. Helsinki: Gaudeamus. Heinonen, Harri (2005). Jalkapallon lumo. Tutkimus suomalaisesta Everton-faniudesta. Jyväskylä: Atena.

Highfield, Tim (2013). Following the yellow jersey. Tweeting the Tour de France. Teoksessa: Weller, Katrin; Bruns, Axel; Burgess, Jean; Mahrt, Merja \& Puschmann, Cornelius (toim.). Twitter and Society. New York: Peter Lang, 249-262.

Highfield, Tim; Harrington, Stephen \& Bruns, Axel (2013). Twitter as the technology for audiencing and fandom. The \#Eurovision phenomenon. Information, Communication Q Society. 16:3, 315-339.

Jenkins, Henry (2006a). Convergence Culture. Where Old and New Media Collide. New York: New York University Press.

Jenkins, Henry (2006b). Fans, Bloggers, and Gamers: Exploring Participatory Culture. New York: NYU Press. Jokinen, Arja; Juhila, Kirsi \& Suoninen, Eero (1993). Diskurssianalyysin aakkoset. Tampere: Vastapaino.

Kolamo, Sami (2014). Fifan valtapeli. Etelä-Afrikan jalkapallon MM-kisat 2010 keskitettynä mediaspektaakkelina. Jyväskylä: Nykykulttuuri.

Kolamo, Sami \& Vuolteenaho, Jani (2014). Urbaanit yleisöt propagandan ja brändäyksen palveluksessa. Berliinin olympialaiset 1936 ja Saksan jalkapallon MM-kisat 2006 keskitettyinä (media) spektaakkeleina. Media Q Viestintä 37:1, 62-83.

Larsson, Anders (2013). Tweeting the viewer - Use of Twitter in a talk show context. Journal of Broadcasting Q Electronic Media. 57:2, 135-152.

Matikainen, Janne \& Villi, Mikko (2015). Aktiivinen yleisö? Tutkimus yleisön asenteista sisällön tuottamista ja jakelua sekä verkossa osallistumista kohtaan. Media Q Viestintä. 38:3, 147-164.

Mukherjee, Partha \& Jansen, Bernard (2014). Social TV and the social soundtrack: Significance of second screen interaction during television viewing. Teoksessa: Kennedy, William; Agarwal, Nitin \& Shanchieh, Jay Yang (toim.). Social Computing, Behavioral-Cultural Modeling and Prediction, 317-324.

Nikunen, Kaarina (2005). Faniuden aika. Kolme tapausta televisio-ohjelmien faniudesta vuosituhannen taitteen Suomessa. Tampere: Tampereen yliopisto.

Papacharissi, Zizi (2012). Without you, I'm nothing. Performances od the self on Twitter. International Journal of Communication. 6, 1989-2006.

Qihao Ji \& Arthur A. Raney (2015) Morally Judging Entertainment: A Case Study of Live Tweeting During Downton Abbey. Media Psychology 18:2, 221-242

Raney, Arthur (2006). Why we watch and enjoy mediated sports? Teoksessa: Raney, Arthur \& Jennings, Bryant (toim.). Handbook of Sports and Media. Taylor \& Francis e-Library: Lawrence Erlbaum Associates, 339-357.

Rowe, David \& Hutchins Brett (2014). Globalization and Online Audiences. Teoksessa: Billings, Andrew C. \& Hardin, Marie (toim.). Routledge Handbook of Sport and New Media. New York: Routledge.

Rowe, David \& Baker, Stephanie Alice Baker (2012). "Truly a fan experience"? The cultural politics of the live site. Teoksessa: Krøvel, Roy \& Roksvold, Thore (toim.). We Love to Hate Each Other. Mediated Football Fan Culture. Göteborg: Nordicom.

Schirra, Steven; Sun, Huan \& Bentley, Frank (2014). Together alone: Motivations for live-tweeting a television series. $\mathrm{CHI}$ ' 14 Proceedings of the SIGCHI Conference on Human Factors in Computing Systems, 2441-2450. 
Tuomi, Pauliina (2013). Televisio kohtaa Twitterin. Uudenlaisen katselukokemuksen yhteisöllisyys. Widerscreen. 2-3. Saatavilla: http://widerscreen.fi/numerot/2013-2-3/televisio-kohtaa-twitterinuudenlaisen-katselukokemuksen-yhteisollisyys/ (luettu: 29.3.2016).

Turtiainen, Riikka (2008). Aktiivisen urheilun kantapäillä. Fanaattisia mediaurheilun kuluttajia kategorisoimassa. Teoksessa: Nikunen, Kaarina (toim.). Fanikirja. Tutkimuksia nykykulttuurin faniilmiöistä. Nykykulttuuri, 43-71.

VISK = Hakulinen, Auli; Vilkuna, Maria; Korhonen, Riitta; Koivisto, Vesa; Heinonen, Tarja Riitta \& Alho, Irja (2004). Iso suomen kielioppi. Helsinki: Suomalaisen Kirjallisuuden Seura. Saatavilla: http://scripta. kotus.fi/visk/sisallys.php?p=1423 (lainattu 20.4.2016).

Weizman, Elda (2008). Positioning in Media Dialogue. Negotiating roles in the news interview. Amsterdam: John Benjamins Publishing Company.

Wilson, Jason (2011). Playing with politics. Political fans and Twitter faking in post-broadcast democracy. Convergence. 17:4, 445-461.

Wohn, Yvette \& Na, Eun-Kyung (2011). Tweeting about TV: Sharing television viewing experiences via social media message streams. First Monday. 16: 3-7. Saatavilla: http://firstmonday.org/ojs/index. $\mathrm{php/fm/article/view/3368/2779} \mathrm{(luettu:} \mathrm{29.3.2016)}$

Wood, Linda \& Kroger, Rolf (2000). Doing Discourse Analysis. Methods for Studying Action in Talk and Text. London: SAGE.

Wood, Megan \& Baughman, Linda (2012). Glee fandon and Twitter. Something new or more of the same old thing. Communication Studies. 63: 3, 328-344.

Yu, Yang \& Wang, Xiao (2015). World Cup 2014 in the Twitter World: A big data analysis of sentiments in U.S. sports fan's tweets. Computers in Human Behavior. 48, 392-400.

Zimmerman, Don (1998). Identity, context and interaction. Teoksessa: Antaki, Charles \& Widdicombe, Sue (toim.). Identities in Talk. London: SAGE, 87-106. 